๑ Entomologica Fennica. 23 November 2001

\title{
Adult craneflies (Diptera: Nematocera) around springs in southern Finland
}

\author{
Jukka Salmela
}

Salmela, J. 2001: Adult craneflies (Diptera: Nematocera) around springs in southern Finland. — Entomol. Fennica 12: 139-152.

\begin{abstract}
Adult craneflies were collected along 27 springs and springbrooks in 1999 and 2000 in southern Finland (biogeographical provinces of Ab, N, St and Ta). A total of 95 species (24 Tipulidae, 2 Cylindrotomidae, 54 Limoniidae, 12 Pediciidae and 3 Ptychopteridae) and 2714 individuals were identified. The material was collected by Malaise and window traps and by sweep netting. Tricyphona immaculata (Meigen), Pedicia rivosa (Linnaeus), P. straminea (Meigen) and Paradelphomyia fuscula (Loew) were the most common and often most abundant species. Erioptera pederi Tjeder, Molophilus bifidus Goetghebuer, M. bihamatus de Meijere, $M$. corniger de Meijere, Lipsothrix ecucullata Edwards, Dicranota pavida (Haliday) and Ula mixta Starý are reported for the first time from Finland.
\end{abstract}

Jukka Salmela, Department of Bio- and Environmental Sciences, University of Jyväskylä, P.O. Box 35, FIN-40351 Jyväskylä, Finland; E-mail: jueesalm@jyv.fi

Received 31 January 2001, accepted 5 May 2001

\section{Introduction}

In temperate regions springs are summer cool and winter warm habitats and they provide a relatively stable environment: constant flow and temperature regime. Northern, cold stenothermic species might have relict populations in springs in southern latitudes and southern species, which are not able to tolerate below $0{ }^{\circ} \mathrm{C}$ winter temperatures, are able to survive in springs in northern latitudes (e.g. Nielsen 1950). Perhaps no aquatic insect is strictly confined to spring habitats, but in some parts of their range they may occur exclusively in springs (Lindegaard 1995, Wagner et. al. 1998).

In this study the major spring types are classified as in Smith (1991): (1) Helocrene: habitat in which emergent groundwater continuously percolates through a layer of detritus or a mat of vegetation; (2) Rheocrene: habitat in which emergent groundwater flows over a substrate consisting primarily of gravel or sand; (3) Limnocrene: habitat in which emergent groundwater forms a stenothermic pool. Often the types co-occur, for instance when a spring has both helocrene and rheocrene characteristics (Table 1). Emergent groundwater flows downstream in a springbrook, and with increased distance from a spring source, the physical characteristics of the springbrook change and become more like the characteristics of surface-fed streams in the same area (e.g. McCabe 1998).

The dipteran families Tipulidae, Cylindrotomidae, Limoniidae, Pediciidae and Ptychopteridae are found througout the Palaearctic region and their larvae inhabit a diverse array of habitats like moist or dry soil, decaying wood, fungi and terrestrial plants. However, a majority of limoniid, pediciid and ptychopterid species and some genera of Tipulidae and Cylindrotomidae are considered to be aquatic/semiaquatic or their larvae dwell in thin films of running water (madicolous or hygropetric habitats) (e.g. Mendl 1978, 


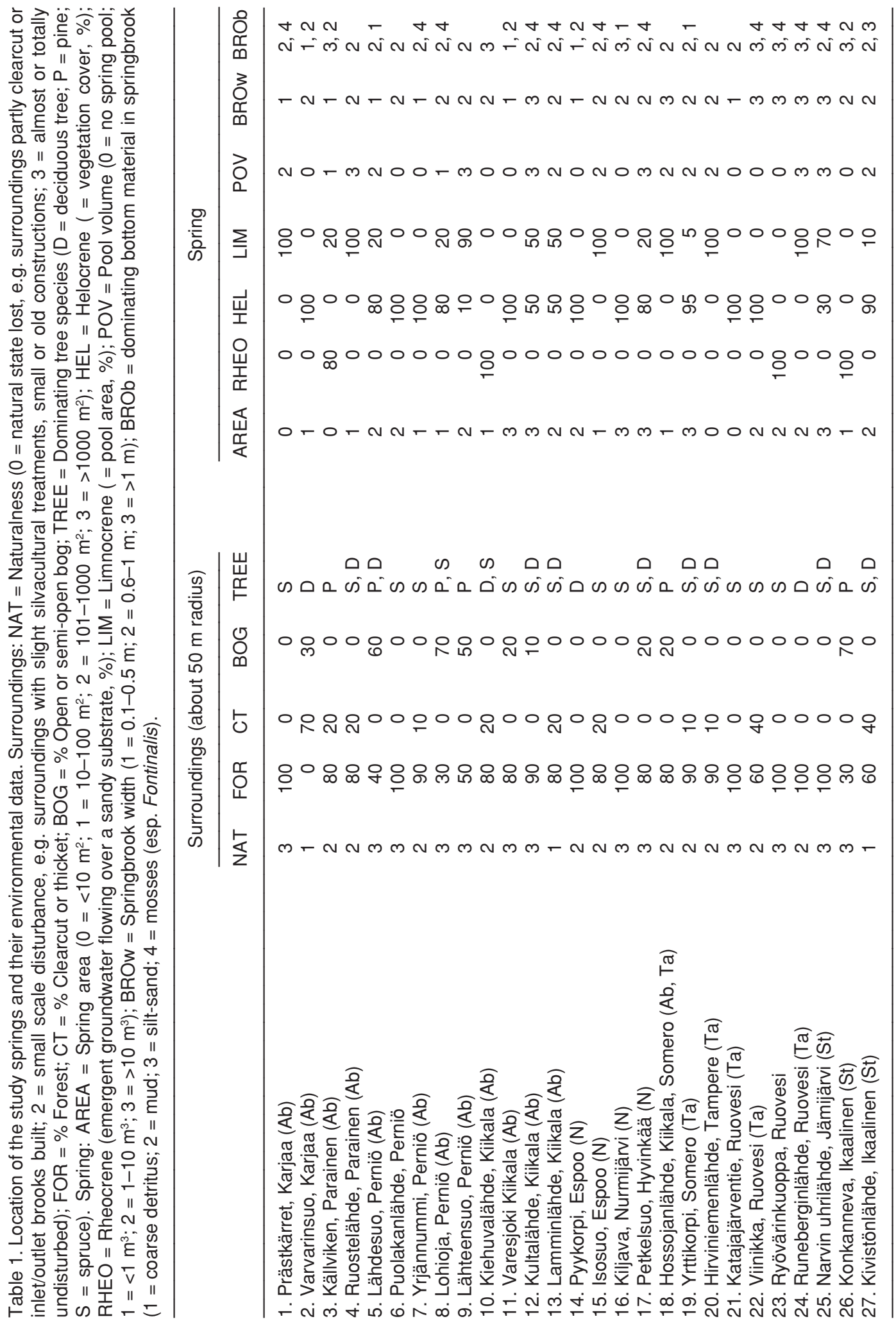


Theowald 1978). Some members of the family Tipulidae are important in detritus processing (Caspers 1980a) and pediciids may be the top invertebrate predators in small and shallow water bodies, like springs (Iversen 1988).

The Finnish cranefly fauna, especially families Limoniidae and Pediciidae, is relatively poorly known; both faunistic and ecological notes are scarce. Only two recent papers dealing with the cranefly fauna of northern Finland are available (Siitonen 1984, Viramo 1992).

In northern Europe invertebrates of springs have been studied mainly in Denmark (e.g. Lindegaard et. al. 1998). However, the methods used in these studies, including only benthic samples, have not made it possible to identify craneflies to species level due to the poor knowledge of the immature stages. In contrast, many emergence or larval breeding studies have been performed in Central Europe and the cranefly fauna of springs and springbrooks is relatively well known in these areas (Dittmar 1955, Gümbel 1976, Maiworm 1984, Fischer et al. 1998, Sternberg 1998, Wagner et al. 1998). These studies show that craneflies can be abundant and species diversity can be high in springs.

\section{Material and methods}

Adult craneflies were collected in 1999 and 2000 by Malaise or window traps or by sweeping adult insects among vegetation with a sweep net. Ethylene glycol or formaldehyde was used as preservative in the traps and the insects were preserved in $70 \%$ alcohol. The collecting intervals varied between two weeks and two months. The material collected by the sweep net was immediately stored in alcohol. The sampling intensity varied between springs: some were sweepnetted only once and others were very intensively sampled, using several Malaise and window traps and sweepnetting on multiple occasions (Table 2.). The samples were taken within a $30 \mathrm{~m}$ radius from the groundwater discharge area. Locations of the study springs and their environmental data are given in Table 1.

Most craneflies could be identified with a dissecting microscope, but some species of Paradelphomyia, Pilaria, Lipsothrix, Dicranota and Ula were mounted on microscope slides and studied later under a higher magnification. Identifications are based mainly on male genitalia. Species and their abundances in each spring are given in the Appendix. Nomenclature and order for Tipulidae is after Oosterbroek and Theowald (1992), for Cylindrotomidae after Soós and Oosterbroek (1992), for Limoniidae and Pediciidae after Reusch and Oosterbroek (1997) and for Ptychopteridae after Rozkosný (1992).

\section{Observations on the occurence of some species and comments on their ecology}

\subsection{Tipulidae}

Altogether 24 (27\% of the Finnish species) tipulid species were recorded. A majority of the species were caught only once and in low numbers of individuals. Along with these occasional species, Tipula fulvipennis, $T$. variicornis and $T$. grisescens occured in eight or more springs, but never in large numbers of individuals. Tipula fulvipennis and $T$. variicornis have a wide distribution in Europe (Oosterbroek \& Theowald 1992) and are only occasionally reported in springs or springbrooks (Dittmar 1955, Maiworm 1984); their larvae may dwell in terrestrial, semiaquatic or hygropetric

Table 2. Sampling methods in springs in southern Finland. Malaise = number of Malaise traps; window $=$ number of window traps; sweepnet $=$ times when visited to sweep net flies.

\begin{tabular}{|c|c|c|c|}
\hline Spring & Malaise & Window & Sweepnet \\
\hline 1. Prästkärret & 1 & - & - \\
\hline 2. Varvarinsuo & 1 & - & - \\
\hline 3. Källvik & - & 1 & 7 \\
\hline 4. Ruostelähde & - & - & 4 \\
\hline 5. Lähdesuo & - & - & 4 \\
\hline 6. Puolakanlähde & - & - & 5 \\
\hline 7. Yrjännummi & - & - & 1 \\
\hline 8. Lohioja & - & - & 4 \\
\hline 9. Lähteensuo & - & - & 4 \\
\hline 10. Kiehuvalähde & - & - & 2 \\
\hline 11. Varesjoki & 2 & - & - \\
\hline 12. Kultalähde & 1 & 3 & 4 \\
\hline 13. Lamminlähde & - & 2 & 2 \\
\hline 14. Pyykorpi & 2 & - & - \\
\hline 15. Isosuo & 1 & - & - \\
\hline 16. Kiljava & 2 & - & 1 \\
\hline 17. Petkelsuo & - & - & 1 \\
\hline 18. Hossojanlähde & - & - & 1 \\
\hline 19. Yrttikorpi & 3 & 4 & 5 \\
\hline 20. Hirviniemenlähde & - & - & 3 \\
\hline 21. Katajajärventie & - & - & 2 \\
\hline 22. Viinikka & - & - & 2 \\
\hline 23. Ryövärinkuoppa & - & 4 & 4 \\
\hline 24. Runeberginlähde & - & 3 & 4 \\
\hline 25. Narvin uhrilähde & - & 2 & 1 \\
\hline 26. Konkanneva & - & 2 & 2 \\
\hline 27. Kivistönlähde & - & 2 & 2 \\
\hline
\end{tabular}


habitats (Theowald 1978, Brinkmann 1991). Tipula grisescens has a boreo-alpine distribution (Theowald \& Oosterbroek 1985) and it is reported from subalpine elevations in Norway (Hofsvang et al. 1987) and Switzerland (Dufour 1992) and rarely from springs (Dittmar 1955). The larvae of the subgenus Satshenkia, like T. grisescens and five other Savtshenkia species collected in this study, are found near water margins or in wet moss (Hofsvang \& Hågvar 1976, Dufour 1992).

Dolichopeza albipes and Tipula maxima are typical species in springs in Central Europe (Wagner et al. 1998), but in this study they both were only collected in a single locality, Varesjoki, Kiikala. Tipula alpium, collected in Pyykorpi spring, has earlier been recorded only once in Finland, Turku (Ab) (Rautio 1986).

Flight periods of the family Tipulidae are given in Table 3. A great part of the adult tipulids were caught in June and July, but T. subnodicornis and $T$. grisescens seem to be vernal and $T$. interserta,
T. pagana and T. limbata autumnal species (see Hofsvang et al. 1993).

\subsection{Cylindrotomidae}

Two cylindrotomids, Phalacrocera replicata (aquatic) and Cylidrotoma distinctissima (terrestrial), were recorded in this study. Adult flies of Cylindrotoma distinctissima were recorded from June till September and $P$. replicata in June. Phalacrocera replicata, whose larvae live within mosses in lentic and slowly flowing waters (Peus 1952), was trapped only from one spring. Brodo (1995) noted $P$. replicata from a small pond above the tree line in South Norway.

\subsection{Limoniidae}

Altogether 54 species of the family Limoniidae

Table 3. Temporal succession of Tipulidae around springs in southern Finland. $I=$ first two weeks of the month and $\mathrm{II}=$ the latter part of the month. $1=1-10$ individuals; $2=11-30$ ind. and $3=>30$ ind .

\begin{tabular}{|c|c|c|c|c|c|c|c|c|c|c|}
\hline \multirow[t]{2}{*}{ Species } & \multicolumn{2}{|c|}{ May } & \multicolumn{3}{|c|}{ June/July } & \multirow{2}{*}{$\begin{array}{l}\text { Aug } \\
\text { I-II }\end{array}$} & \multicolumn{2}{|c|}{ Sep } & \multicolumn{2}{|c|}{ Oct } \\
\hline & I & II & 1 & II-I & II & & I & II & I & II \\
\hline Tipula subnodicornis & 1 & 1 & 1 & - & - & - & - & - & - & - \\
\hline Tipula grisescens & 1 & 2 & - & - & - & - & - & - & - & - \\
\hline Tipula variipennis & - & 1 & 1 & - & - & - & - & - & - & - \\
\hline Tipula nubeculosa & - & 1 & 2 & 1 & - & - & - & - & - & - \\
\hline Dictenidia bimaculata & - & 1 & - & 1 & - & - & - & - & - & - \\
\hline Tipula variicornis & - & - & 1 & 3 & 1 & - & - & - & - & - \\
\hline Tanyptera nigricornis & - & - & 1 & - & - & - & - & - & - & - \\
\hline Tanyptera atrata & - & - & 1 & - & - & - & - & - & - & - \\
\hline Tipula fulvipennis & - & - & 1 & 1 & 1 & - & - & - & - & - \\
\hline Tipula irrorata & - & - & 1 & 1 & - & - & - & - & - & - \\
\hline Tipula lateralis & - & - & & 1 & - & - & - & - & - & - \\
\hline Tipula lunata & - & - & 1 & 1 & - & - & - & - & - & - \\
\hline Tipula scripta & - & - & 1 & 1 & - & - & - & - & - & - \\
\hline Tipula unga & - & - & - & 1 & - & - & - & - & - & - \\
\hline Nephrotoma flavescens & - & - & - & 1 & - & - & - & - & - & - \\
\hline Tipula fascipennis & - & - & - & 1 & - & - & - & - & - & - \\
\hline Tipula limitata & - & - & - & 1 & - & - & - & - & - & - \\
\hline Tipula alpium & - & - & - & 1 & - & - & - & - & - & - \\
\hline Dolichopeza albipes & - & - & - & 1 & - & - & - & - & - & - \\
\hline Tipula maxima & - & - & - & 1 & - & - & - & - & - & - \\
\hline Tipula paludosa & - & - & - & - & - & 1 & - & - & - & - \\
\hline Tipula interserta & - & - & - & - & - & - & - & 1 & - & - \\
\hline Tipula pagana & - & - & - & - & - & - & - & 1 & - & - \\
\hline Tipula limbata & - & - & - & - & - & - & - & 1 & - & - \\
\hline
\end{tabular}


were identified in this material, which comprises $34 \%$ of the Finnish limoniids. Neolimnomyia nemoralis, Paradelphomyia fuscula, Erioptera lutea, Molophilus flavus, Ormosia depilata, Scleroprocta sororcula and Limonia macrostigma were the most common species, with nine or more records. Neolimnomyia nemoralis, E. lutea and L. macrostigma are ubiquitous species, which can be found in a wide range of habitats, both terrestrial and aquatic (Brinkmann 1991). They have also been reported to attain relatively high densities in spring habitats (Gümbel 1976, Maiworm 1984, Sternberg 1998). According to Wagner et al. (1998) $P$. fuscula is a common shredder in Central European springs, but also occurs in small brooks (Mendl 1978). Paradelphomyia fuscula was the most abundant limoniid in Yrttikorpi and $M$. flavus in Varesjoki and Pyykorpi localities. Molophilus flavus inhabits small lotic waters (Mendl 1978), spring-fed brooks (Maiworm 1984) and it is classified as an alpine/subalpine species in Norway (Solem \& Mendl 1989). Ormosia depilata and S. sororcula are both reported from spring brooks and brooks (Mendl 1973, Caspers 1980b, Maiworm 1984, Fischer et al. 1998, Sternberg 1998), but perhaps O. depilata is more eurytopic in relation to moisture and discharge than S. sororcula (Mendl 1978, Brinkmann 1991).

Flight periods of the Limoniidae are given in Table 4. Some species with long flight periods (e.g. E. lutea, Metalimnobia quadrinotata and Dicranomyia modesta) had obviously two generations per year (see Brinkmann 1991). Scleroprocta sororcula and $O$. depilata had their maximal occurence in May, M. flavus in June and July, P. fuscula and Rhypholophus haemorrhoidalis in August.

Five of the limoniids reported here are new to the Finnish fauna: Erioptera pederi, Molophilus bifidus, M. bihamatus, M. corniger and Lipsothrix ecucullata. Tjeder (1969) described E. pederi from Skåne, Sweden and the type locality was "a small, cold brook". In addition to the type locality $E$. pederi is reported from Central Europe, Rumania and from Asia, Taijikistan and Kirgisia (Savchenko et al. 1992). Mendl (1973) and Mendl (1976) observed E. pederi from brooks in Germany. Molophilus bifidus was collected only from Varesjoki spring-fed brook. It seems to be a typical brook and springbrook species (Mendl 1973,
Caspers 1980b, Maiworm 1984, Sternberg 1998) with semiaquatic larvae (Mendl 1978, Brinkmann 1991). Molophilus bihamatus was collected from a single locality, Runebergin lähde limnocrene spring and springbrook with herb-rich forest surroundings; its larvae are semiaquatic or terrestrial (Mendl 1978, Brinkmann 1991). The third new Molophilus species, M. corniger, was more common than the preceeding ones: it was trapped from Kultalähde, Yrttikorpi and Kiljava springs. Molophilus corniger has earlier been reported from brooks and springbrooks (Maiworm 1984, Sternberg 1998), and the larvae are probably aquatic or semiaquatic (Mendl 1978). Lipsothrix ecucullata was collected altogether from four springs. The genus Lipsothrix is not included in Limnofauna Europea (Mendl 1978), but according to Dudley and Anderson (1987) and Ward (1992) the larvae of Lipsothrix dwell in logs in running waters. Three species of Lipsothrix are known to occur in North Europe and this is the first record of this genus in Finland (Savchenko et al. 1992).

\subsection{Pediciidae}

The twelve species of Pediciidae found cover $71 \%$ of the known Finnish pediciid species. Pedicia straminea, $P$. rivosa, Tricyphona immaculata and $T$. livida were the most common and often the most abundant pediciids. These four species coexisted in seven springs and they comprised $44 \%$ of all collected individuals.

Pedicia straminea and P. rivosa are very common predators in springs in Europe (Dittmar 1955, Lindegaard \& Thorup 1975, Gümbel 1976, Maiworm 1984, Iversen 1988, Fischer et al. 1998, Lindegaard et al. 1998, Sternberg 1998, Wagner et al. 1998), but they both live also in other habitats (Mendl 1978).

Tricyphona immaculata was the most common and abundant species in this study: it was recorded from 21 springs, and it was the most numerous species at six localities. Like $P$. strami$n e a$ and $P$. rivosa, it is a common spring dweller in Europe, and it also occurs in a wide area and many kind of biotopes in North Europe (Mannheims 1972, Solem \& Mendl 1989, Viramo 1992, Brodo 1995). Brinkmann (1991) found it to inhabit all gradients between terrestrial and aquatic. 
Table 4. Temporal succession of Limoniidae around springs in southern Finland. I = first two weeks of the month and $\mathrm{II}=$ the latter part of the month. $1=1-10$ individuals; $2=11-30$ ind. and $3=>30$ ind.

\begin{tabular}{|c|c|c|c|c|c|c|c|c|c|c|}
\hline \multirow[t]{2}{*}{ Species } & \multicolumn{2}{|c|}{ May } & \multicolumn{3}{|c|}{ June/July } & \multirow{2}{*}{$\begin{array}{l}\text { Aug } \\
\text { |-II }\end{array}$} & \multicolumn{2}{|c|}{ Sep } & \multicolumn{2}{|c|}{ Oct } \\
\hline & I & II & I & $\|-1$ & II & & I & II & I & II \\
\hline Ormosia lineata & 1 & 1 & - & - & - & - & - & - & - & - \\
\hline Hoplolabis vicina & 1 & - & - & - & - & - & - & - & - & - \\
\hline Scleroprocta sororcula & - & 2 & 1 & 1 & - & - & - & - & - & - \\
\hline Idioptera macropteryx & - & 1 & 1 & - & - & - & - & - & - & - \\
\hline Erioptera pederi & - & 1 & - & - & - & - & - & - & - & - \\
\hline Austrolimnophila unica & - & 1 & - & - & - & - & - & - & - & - \\
\hline Ormosia depilata & - & 3 & 2 & 1 & - & - & - & - & - & - \\
\hline Cheilotrichia cinerascens & - & 1 & - & - & - & - & - & - & - & - \\
\hline Erioptera sordida & - & 1 & - & - & - & - & - & - & - & - \\
\hline Erioptera lutea & - & 2 & 1 & 2 & 1 & 1 & - & - & - & - \\
\hline Dicranomyia fusca & - & 1 & - & 1 & - & - & - & - & - & - \\
\hline Molophilus ater & - & 1 & - & - & - & - & - & - & - & - \\
\hline Lipsothrix sp. & - & - & 1 & - & - & - & - & - & - & - \\
\hline Neolimnomyia nemoralis & - & - & 1 & 2 & 1 & - & - & - & - & - \\
\hline Molophilus flavus & - & - & 3 & 3 & 1 & 1 & - & - & - & - \\
\hline Dicranomyia distendens & - & - & 1 & - & - & - & - & - & - & - \\
\hline Metalimnobia zetterstedti & - & - & 1 & 1 & 1 & - & - & - & - & - \\
\hline Metalimnobia quadrinotata & - & - & 1 & 3 & 1 & 1 & 1 & - & - & - \\
\hline Eloeophila maculata & - & - & 1 & 1 & - & - & - & - & - & - \\
\hline Limonia nubeculosa & - & - & 1 & 1 & - & - & - & - & - & - \\
\hline Euphylidorea phaeostigma & - & - & 1 & 1 & - & - & - & - & - & - \\
\hline Euphylidorea fulvonervosa & - & - & 1 & 1 & 1 & 1 & - & - & - & - \\
\hline Epiphragma ocellare & - & - & 1 & 1 & - & - & - & - & - & - \\
\hline Tasiocera murina & - & - & 1 & 1 & - & - & - & - & - & - \\
\hline Dicranomyia modesta & - & - & 1 & 1 & - & 1 & - & - & 1 & - \\
\hline Limonia stigma & - & - & 1 & - & 1 & - & - & - & - & - \\
\hline Helius longirostris & - & - & - & 1 & - & - & - & - & - & - \\
\hline Molophilus medius & - & - & - & 1 & - & - & - & - & - & - \\
\hline Erioptera flavata & - & - & - & 1 & - & - & - & - & - & - \\
\hline Neolimonia dumetorum & - & - & - & 1 & - & - & - & - & - & - \\
\hline Phylidorea squalens & - & - & - & 1 & - & - & - & - & - & - \\
\hline Molophilus appendiculatus & - & - & - & 1 & 1 & 1 & - & - & - & - \\
\hline Molophilus bihamatus & - & - & - & - & 1 & - & - & - & - & - \\
\hline Limonia macrostigma & - & - & 1 & 1 & 2 & 1 & 1 & - & - & - \\
\hline Dicranomyia frontalis & - & - & - & - & - & 1 & - & - & - & - \\
\hline Pilaria scutellata & - & - & - & - & - & 1 & - & - & - & - \\
\hline Limonia quadrimaculata & - & - & - & 1 & 1 & 1 & - & - & - & - \\
\hline Ormosia ruficauda & - & - & - & 1 & - & - & - & - & - & - \\
\hline Molophilus bifidus & - & - & - & 2 & - & - & - & - & - & - \\
\hline Rhipidia maculata & - & - & - & 1 & - & 1 & - & - & 1 & - \\
\hline Dicranomyia didyma & - & - & - & - & - & 1 & - & - & - & - \\
\hline Metalimnobia bifasciata & - & - & - & 1 & 1 & 1 & 1 & - & - & - \\
\hline Lipsothrix ecucullata & - & - & - & 1 & - & - & - & - & - & - \\
\hline Molophilus corniger & - & - & - & 2 & 1 & - & - & - & - & - \\
\hline Dicranomyia terranovae & - & - & - & - & - & 1 & - & - & - & - \\
\hline Paradelphomyia fuscula & - & - & - & 1 & 2 & 3 & - & - & 1 & - \\
\hline Limonia phragmitidis & - & - & - & 1 & 1 & - & - & - & - & - \\
\hline Dicranomyia rufiventris & - & - & - & - & - & 1 & - & - & - & - \\
\hline Rhypholophus haemorrhoidalis & - & - & - & - & - & 2 & - & - & - & - \\
\hline Discobola annulata & - & - & - & - & - & 1 & 1 & - & - & - \\
\hline Rhypholophus varius & - & - & - & - & - & 2 & - & - & - & - \\
\hline Dicranomyia halterella & - & - & - & - & - & 2 & 1 & - & - & - \\
\hline Dicranomyia stigmatica & - & - & - & - & - & - & 1 & 1 & - & - \\
\hline Dicranomyia autumnalis & - & - & - & - & - & - & - & - & 1 & - \\
\hline Chionea lutescens & - & - & - & - & - & - & - & - & - & 1 \\
\hline
\end{tabular}


Table 5. Temporal succession of Pediciidae around springs in southern Finland. $I=$ first two weeks of the month and $\mathrm{II}=$ the latter part of the month. $1=1-10$ individuals; $2=11-30$ ind. and $3=>30$ ind.

\begin{tabular}{|c|c|c|c|c|c|c|c|c|c|c|}
\hline \multirow[t]{2}{*}{ Species } & \multicolumn{2}{|c|}{ May } & \multicolumn{3}{|c|}{ June/July } & \multirow{2}{*}{$\begin{array}{l}\text { Aug } \\
\text { I-II }\end{array}$} & \multicolumn{2}{|c|}{ Sep } & \multicolumn{2}{|c|}{ Oct } \\
\hline & I & II & I & $I I-1$ & II & & I & II & I & II \\
\hline Dicranota guerini & 1 & - & - & - & - & - & - & - & - & - \\
\hline Ula sylvatica & 1 & - & 1 & - & - & - & - & - & - & - \\
\hline Ula mixta & - & 1 & - & - & - & 1 & - & - & - & - \\
\hline Tricyphona unicolor & - & 1 & - & - & - & - & - & - & - & - \\
\hline Tricyphona immaculata & - & 3 & 3 & - & - & - & - & - & - & - \\
\hline Dicranota bimaculata & - & 1 & - & - & - & 1 & - & - & - & - \\
\hline Pedicia rivosa & - & 1 & 3 & 3 & 2 & 2 & 1 & - & 1 & - \\
\hline Dicranota pavida & - & - & - & 1 & 1 & 1 & - & - & - & - \\
\hline Dicranota exclusa & - & - & - & 1 & 1 & - & - & - & - & - \\
\hline Tricyphona schummeli & - & - & - & 1 & - & 1 & - & - & - & - \\
\hline Tricyphona livida & - & - & - & 1 & 3 & 2 & - & - & - & - \\
\hline Pedicia straminea & - & - & 1 & 2 & 2 & 3 & 3 & 1 & 2 & - \\
\hline
\end{tabular}

Tricyphona livida was found to inhabit 10 springs, though earlier it has been found from Finland only once, from Kuusamo (Ks) (Viramo 1992). This species has a wide distribution, but it is not reported from other Nordic countries (Savchenko et al. 1992). It is apparently a rare species in Central Europe: the only ecolocigal information concerning T. livida, brook and small lotic water species, is given by Mendl (1978).

Tricyphona schummeli occured in Lamminlähde, Lähdesuo and Pyykorpi springs. Mendl (1978) regarded it as a spring species, Dittmar (1955) mentioned a muddy spring area as a larval habitat. Tricyphona schummeli is widely distributed in Europe (Savchenko et al. 1992), but ecological notes are scarce (Noll 1985) and it often occurs in low numbers of individuals (e.g. Sandrock 1978, Noll 1985).

The adults of $T$. immaculata were caught in May and June (Table 5). The species may have two generations in North Germany (Brinkmann 1991) and South Sweden (Tjeder 1959), but apparently only one around springs in southern Finland. Pedicia rivosa had a long flight period, from May till October, but maximum occurence in June and July. Tricyphona livida and $P$. straminea flew in late summer and autumn.

Dicranota pavida was collected from Varesjoki, Runebergin lähde and Uhrilähde springs. Dicranota pavida is widely distributed in Europe, but it has not been found earlier from Finland (Savchenko et al. 1992). The species is quite fre- quently reported along brooks and springbrooks (Mendl 1973, Gümbel 1976, Sandrock 1978, Caspers 1980b, Maiworm 1984, Mendl et al. 1987). The other new pediciid, Ula mixta, was described from Slovakia by Starý (1983), and in addition to the type localities, is known only from Germany and Norway (Savchenko et al. 1992). Immature stages of Ula inhabit woody or fleshy fungi.

\subsection{Ptychopteridae}

Three species of the family Ptychopteridae were identified. Ptychoptera scutellaris was caught in May and P. lacustris and P. minuta in June-July. Ptychopterids were trapped only occasionally; larval development occurs perhaps rarely in springs. However, Ptychoptera lacustris is regularly found in Central European springs (Wagner et al. 1998).

\section{Discussion}

The present study gives a noticeable contribution to the knowledge of the distribution and phenology of adult craneflies in southern Finland. However, further studies are needed to clarify the distribution and status of certain species: are they, for example, confined to the spring areas only. In this study no larvae were investigated and the 
microdistribution of immature stages remains unknown, but Brinkmann (1991) noted, in his study from a lowland brook in North Germany, that that cranefly community mainly developed in the banks of the brook. Brinkmann (1991) grouped the craneflies with regard to humidity in the following way (the species listed after the groups were found in this study): (1) eurytopic species in relation to the water level (Cheilotrichia cinerascens, Erioptera lutea, Tricyphona immaculata), (2) terrestrial species of the dryest locations (Limonia nubeculosa, Neolimonia dumetorum, Rhypholophus varius, Tipula irrorata, Tipula scripta), (3) terrestrial species of the more humid locations (potential semiaquatic species) (Limonia macrostigma, Limonia tripunctata (syn. phragmitidis), Molophilus appendiculatus, M. bihamatus, Ormosia depilata, Tipula variicornis), (4) potential aquatic species: a) species which inhabit moist sand or mud at the waters edge (Tipula maxima), b) species which inhabit marshes and swamps (Erioptera gemina (syn. flavata), Erioptera sordida, Euphylidorea fulvonervosa, Helius longirostris), (5) aquatic species (in general, running water species) (Dicranota bimaculata, Eloeophila maculata).

Fischer et al. (1998) classified four zones in relation to the spring fauna: (1) groundwater, spring and springbrook fauna, (2) hygropetric fauna, (3) limnic-terrestrial interface fauna, and (4) terrestrial-hydrophilous fauna. The order Diptera comprised $32 \%, 69 \%$ and $95 \%$ of the community in these zones, respectively (terrestrialhydrophilous fauna excluded). The importance of semiaquatic area for limoniids and pediciids is also discussed in Caspers (1980b).

In a review of the family Chironomidae in European cold springs Lindegaard (1995) separated seven groups: (1) crenobiontic species restricted to the spring area, (2) crenophilous species with maximum abundance in springs, (3) lotic species also living in spring area, (4) lentic species occuring mostly in limnocrenes, (5) ubiquitous species, (6) madicolous species, and (7) terrestrial species. As stated by Lindegaard (1995), apparently no chironomid species is exclusively dependent on the spring biotope. Although Mendl (1978) noted six limoniids and pediciids as spring species, the same conclusion probably applies to craneflies too (see Wagner et al. 1998). One of these spring Limoniidae species classified by Mendl (1978) is represented in the present paper, Tricyphona schummeli. Some limoniids and pediciids, collected around springs in southern Finland, might fit Lindegaard's (1995) second, third or even fifth category: Paradelphomyia fuscula, Molophilus flavus, Pedicia straminea, $P$. rivosa, Tricyphona immaculata and T. livida. Three common limoniids, Neolimnomyia nemoralis, Erioptera lutea and Limonia macrostigma are obviously ubiquitous species. Perhaps after further studies in North Europe in springs and in other biotopes a classification similar to Lindegaard (1995) can be created for craneflies.

To the author's knowledge, this is the first paper dealing with adult craneflies collected in the immediate vicinity of springs in North Europe, and thus meaningful faunistic or ecological comparisons with other Nordic countries cannot be made. However, many papers treating the Limoniidae and Pediciidae fauna of Central European springs and spring brooks are available (Dittmar 1955, Gümbel 1976, Maiworm 1984, Fischer et al. 1998, Sternberg 1998). The total number of species reported in these studies is 72 (66 Limoniidae and Pediciidae in this study) and 30 species are the same as in the present study. It must be remembered that Central European studies are mainly based on emergence catches. It is likely that Malaise traps and window traps and sweepnetting collect insects from a wider area. Because the methods in collecting the material in this study varied so much, differences in the cranefly fauna between springs have not been analysed. However, Lindegaard et al. (1998) found a positive correlation between the area of the spring and species richness. They also noted that spring size and substrate diversity are more important than the amount of groundwater discharge in maintaining high species richness, and the absence/presence of a springbrook influences significantly the faunal composition. In addition to these factors, the madicolous and semiaquatic conditions in the bank area are perhaps the most important factors influencing cranefly species diversity and abundance in springs.

Acknowledgements. I am extremely grateful to M.Sc. Jari Ilmonen and Phil. Lic. Lauri Paasivirta for sampling 
the material, description of the springs and for valuable corrections to the manuscript. I also owe special thanks to Mr. Juha Salokannel for comments on the manuscript and to Mr. Olli Jalonen for linguistic corrections. Editor-in-Chief Niklas Wahlberg, Dr. Pekka Vilkamaa and an anonymous referee critically reviewed an earlier draft of this manuscript, and P. Vilkamaa kindly let me investigate some pediciids in Helsinki Zoological Museum.

\section{References}

Brinkmann, R. 1991: Zur Habitatpräferenz und Phänologie der Limoniidae, Tipulidae und Cylindrotomidae (Diptera) in Bereich eines norddeutschen Tieflandbaches. — Faun. Ökol. Mitt. Suppl. 11: 1-156.

Brodo, F. 1995: Analysis and additions to the crane fly fauna of Finse, South Norway (Diptera: Tipulidae). _ Fauna norv. ser. B 42: 11-20.

Caspers, N. 1980a: Zur Larvalentwicklung und Produktionsökologie von Tipula maxima Poda (Diptera, Nematocera, Tipulidae). - Arch. Hydrobiol. Suppl. 58: 273-309.

Caspers, N. 1980b: Die Emergenz eines kleinen Waldbaches bei Bonn. - Decheniana-Beihefte (Bonn) 23: 1-175.

Dittmar, H. 1955: Ein Sauerlandbach. Untersuchungen an einem Wiesen-Mittelgebirgesbach. - Arch. Hydrobiol. 50: 305-552.

Dudley, T. L. \& Anderson, N. H. 1987: The biology and life cycles of Lipsothrix spp. (Diptera: Tipulidae) inhabiting wood in western Oregon streams. - Freshwat. Biol. 17: 437-451.

Dufour, C. 1992: High altitude Tipulidae in Switzerland (Diptera, Nematocera). — Acta zool. cracov. 35: 113134.

Fischer, J., Fisher, F, Schnabel, S., Wagner, R. \& Bohle, H. W. 1998: Die Quellfauna der Hessischen Mittelgebirsregion. Besiedlungsstruktur, Anpassungsmechanismen und Habitatbindung der Makroinvertebraten am Beispiel von Quellen aus dem Rheinischen Schieferbirge und der osthessischen Buntsandsteinlandschaft. - In: Botosaneanu, L. (ed.), Studies in crenobiology. The biology of springs and springbrooks: 183-199. Backhuys Publishers, Leiden. 261 pp.

Gümbel, D. 1976: Emergenz-Vergleich zweier Mittelgebirgsquellen 1973. Schlitzer Produktionsbiologische Studien (18). - Arch. Hydrobiol. Suppl. 50: 1-53.

Hofsvang, T., Hansen, L. O. \& Midtgaard, F. 1993: Flight periods of Tipulidae (Diptera) from 22 Norwegian localities. - Fauna norv. ser. B 40: 81-87.

Hofsvang, T. \& Hågvar, S. 1976: Density and composition of crane fly larvae (Diptera, Tipulidae) from an alpine wet meadow at Stigstuv, Hardangervidda, South Norway. - Norw. J. Ent. 23: 41-43.

Hofsvang, T., Solem, J. O. \& Bretten, S. 1987: Distribution and seasonal abundance of adult Tipulidae (Diptera) in the Dovrefjell National Park, South Norway. — Fauna norv. ser. B 34: 51-56.

Iversen, T. M. 1988: Secondary production and trophic relationships in a spring invertebrate community. Limnol. Oceanogr. 33: 582-592.

Lindegaard, C. 1995: Chironomidae (Diptera) of European cold springs and factors influencing their distribution. — In: Ferrington, L. C. Jr. (ed.), : Biodiversity of aquatic insects and other invertebrates in springs: 108-131. Journal of the Kansas Entomological Society. 68 suppl. $165 \mathrm{pp}$.

Lindegaard, C. \& Thorup, J. 1975: The invertebrate fauna of the moss carpet in the Danish spring Ravnkilde and its seasonal, vertical, and horizontal distribution. Arch. Hydrobiol. 75: 109-139.

Lindegaard, C., Brodersen, K. P., Wiberg-Larsen, P. \& Skriver, J. 1998: Multivariate analyses of macrofaunal communities in Danish springs and springbrooks. In: Botosaneanu, L. (ed.), Studies in crenobiology. The biology of springs and springbrooks: 201-219. Backhuys Publishers, Leiden. 261 pp.

Mannheims, B. 1972: The invertebrate fauna of the Kilpisjärvi area, Finnish Lapland. 16. Diptera Tipuloidea. Acta. Soc. Pro Fauna et Flora Fennica 80: 233-237.

Maiworm, M. 1984: Die Insektenfauna sauerländischer Fliebgewässer. — Decheniana (Bonn) 137: 203-225.

McCabe, D. J. 1998: Biological communities in springbrooks. - In: Botosaneanu, L. (ed.), Studies in crenobiology. The biology of springs and springbrooks: 221-228. Backhuys Publishers, Leiden. 261 pp.

Mendl, H. 1973: Limoniinen aus dem Breitenbach (Diptera, Tipulidae). Schlitzer Produktionsbiologische Studien (4). - Arch. Hydrobiol. 71: 255-270.

Mendl, H. 1976: Limoniiden (Diptera, Nematocera) aus dem Allgäu. - Mitt. Münch. Ent. Ges. 66: 101-125.

Mendl, H. 1978: Limoniidae. — In: Illies, J. (ed.), Limnofauna Europea: 367-377. G. Fischer Verlag / Swets \& Zeitlinger B. V. 532 pp.

Mendl, H., Solem, J. O. \& Bretten, S. 1987: Distribution and seasonal abundance of adult Limoniidae (Insecta, Diptera, Nematocera) in the Dovrofjell National Park, South Norway. - Fauna norv. ser. B 34: 63-72.

Nielsen, A. 1950: On the zoogeography of springs. Hydrobiologia 2: 313-321.

Noll, R. 1985: Taxonomie und Ökologie der Tipuliden, Cylindrotomiden, Limoniiden und Trichoceriden unter besonderer Berücksichtigung der Fauna Ostwestfalens (Insecta: Diptera). — Decheniana-Beihefte 28: 1-265.

Oosterbroek, P. \& Theowald, Br. 1992: Family Tipulidae. —In: Soós, A., Papp, L. \& Oosterbroek, P. (eds.), Catalogue of the Palaearctic Diptera: 56-178. Hungarian Natural History Museum, Budapest, 1: 1-463.

Peus, F. 1952: 17. Cylindrotomidae. — In: Lindner, E. (ed.), Die Fliegen der Palaearktischen Region. Lfg. 169: 180.

Rautio, O. 1986: Suomelle uusi vaaksiainen (Tipulidae). — Notulae Entomologicae 66: 190. (In Finnish).

Reusch, H. \& Oosterbroek, P. 1997: Diptera Limoniidae and Pediciidae, Short-palped Crane Flies. - In: 
Nilsson, A. N. (ed.), Aquatic Insects of Noth Europe - A Taxonomic Handbook: 105-132. Vol. 2. 440 pp. Rozkosný, R. 1992: Family Ptychopteridae. - In: Soós, A., Papp, L. \& Oosterbroek, P. (eds.), Catalogue of the Palaearctic Diptera: 370-373. Hungarian Natural History Museum, Budapest, 1: 1-463.

Sandrock, F. 1978: Vergleichende Emergenzmessung an zwei Bächen des Schlitzerlandes (Breitenbach und Rohrwiesenbach 1970-1971). Schlitzer Produktionsbiologische Studien (24). - Arch. Hydrobiol. Suppl. 54: 328-408.

Savchenko, E. N., Oosterbroek, P. \& Starý, J. 1992: Family Limoniidae. - In: Soós, Á., Papp, L. \& Oosterbroek, P. (eds.), Catalogue of the Palaearctic Diptera: 183374. Hungarian Natural History Museum, Budapest, 1: $1-463$.

Siitonen, O. 1984: Tipuloidea (Diptera) of Inari Lapland. - Kevo Notes 7: 67-69.

Smith, I. M. 1991: Water mites (Acari: Parasitengona: Hydrachnida) of spring habitats in Canada - In: Williams, D. D. and Danks, H. V. (eds.), Arthopods of springs, with particular reference to Canada: 141-167. Mem. ent. Soc. Can. 155. 217 pp.

Solem, J. O. \& Mendl, H. 1989: Limoniidae communities in alpine and boreal zones along the Atna River, South Norway (Diptera, Nematocera). - Fauna norv. ser. B 36: $107-114$.

Soós, A. \& Oosterbroek, P. 1992: Family Cylindrotomidae. —In: Soós, Á., Papp, L. \& Oosterbroek, P. (eds.), Catalogue of the Palaearctic Diptera. :179-182. Hungarian
Natural History Museum, Budapest, 1: 1-463.

Starý, J. 1983: New taxa of Limoniidae from Czechoslovakia (Diptera). - Annotationes Zoologicae et Botanicae 154: 1-21.

Sternberg, A. 1998: Die Stelzmücken (Limoniidae und Pediciidae, Diptera) zweier Waldquellbiotope in der Rhön (Hessen) und ihre Phänologie. - Lauterbornia H. 32: 101-111, Dinkelscherben, April.

Theowald, B. 1978: Tipulidae und Cylindrotomidae. - In: Illies, J. (ed.), Limnofauna Europea: 363-366. G. Fischer Verlag/Swets \& Zeitlinger B.V. 532 pp.

Theowald, Br. \& Oosterbroek, P. 1985: Zur Zoogeographie der westpaläarktischen Tipuliden VI. Die Tipuliden der montanen, alpinen und borealen Gebiete (Insecta, Diptera, Tipulidae). — Bonn. Zool. Beitr. 36: 185-220.

Tjeder, B. 1959: A synopsis of the Swedish Tipulidae, 2. Subfam. Limoniinae: tribe Pedicini. - Opuscula entomologica 24: 1-9.

Tjeder, B. 1969: Three new Tipulidae from Sweden (Diptera). - Opuscula entomologica 34: 250-256.

Viramo, J. 1992: Craneflies (Diptera, Tipulidae) of the Koillismaa region (Ks). - Oulanka Reports 10: 3340. (In Finnish with English summary).

Wagner, R., Fischer, J. \& Schnabel, S. 1998: The dipteran community of central European springs: a summary. — In: Botosaneanu, L. (ed.), Studies in crenobiology. The biology of springs and springbrooks: 157-165. Bachhuys Publishers, Leiden. 261 pp.

Ward, J. V. 1992: Aquatic insect ecology. 1. Biology and habitat. — John Wiley \& Sons, Inc. 438 pp. 


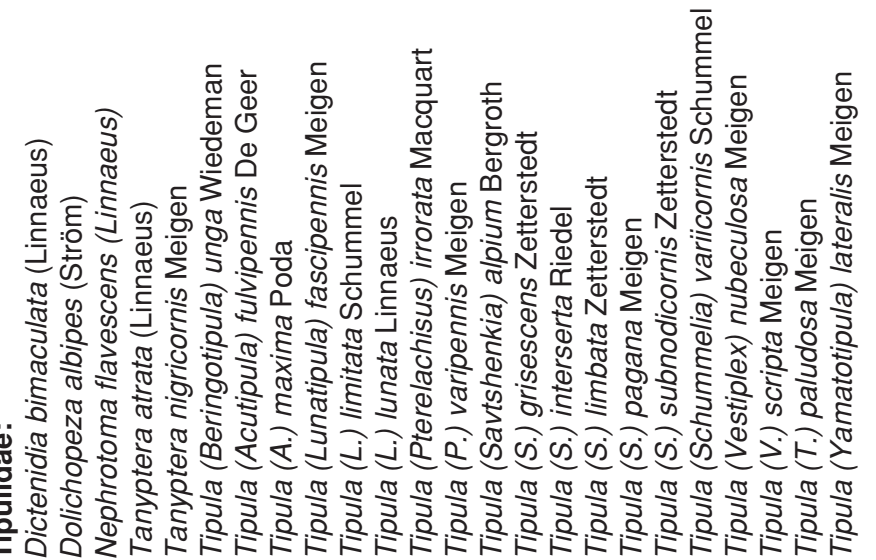




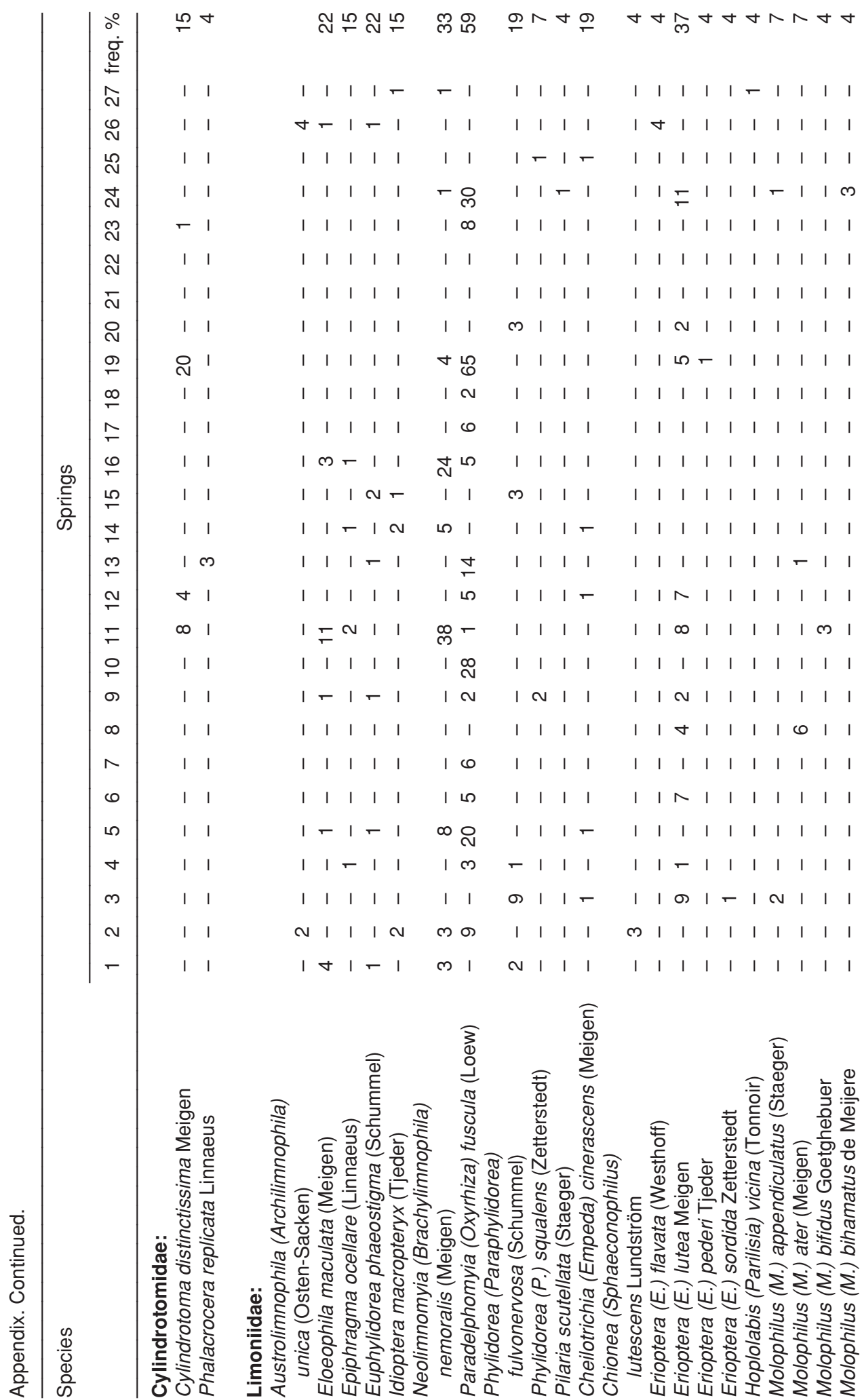



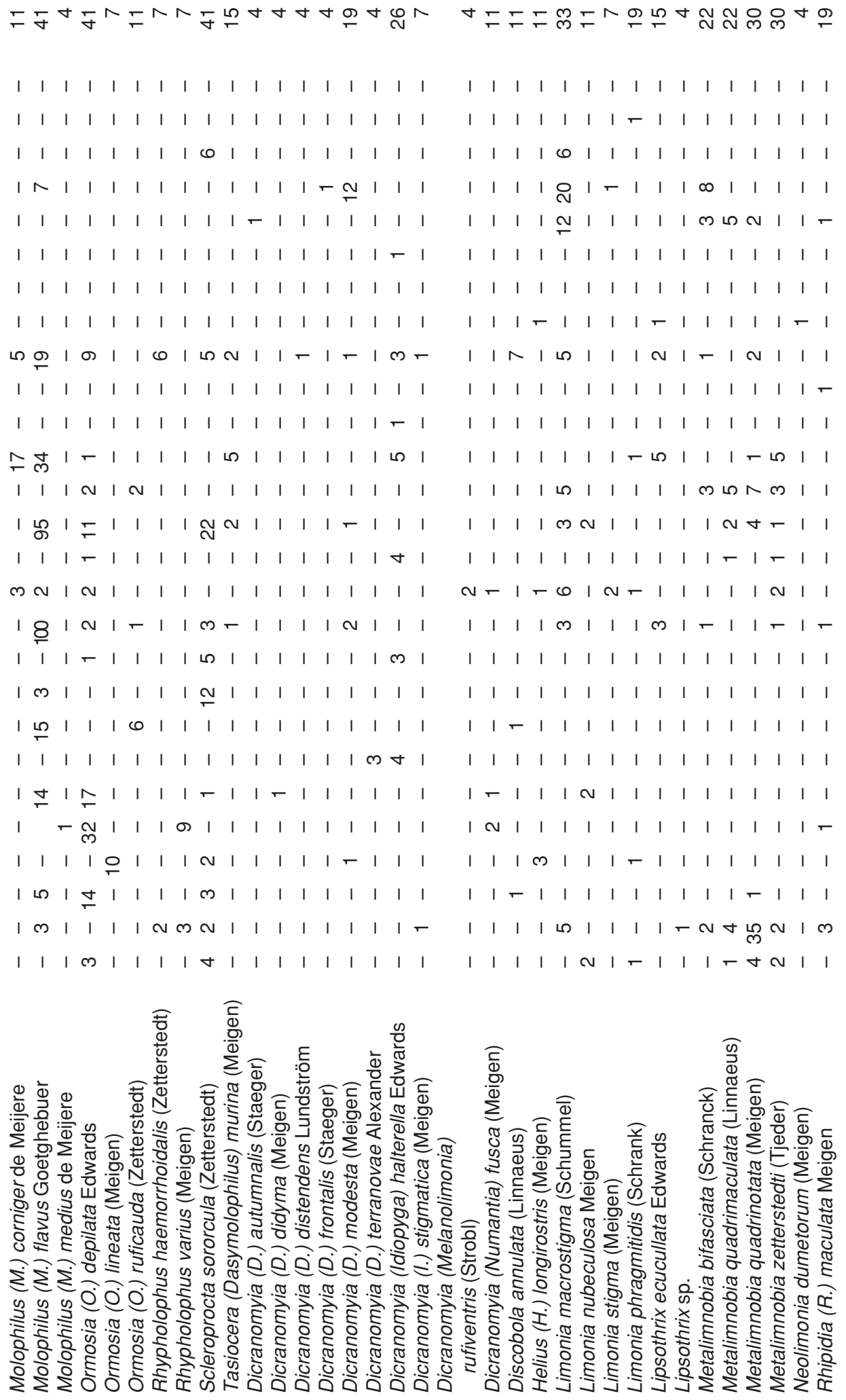


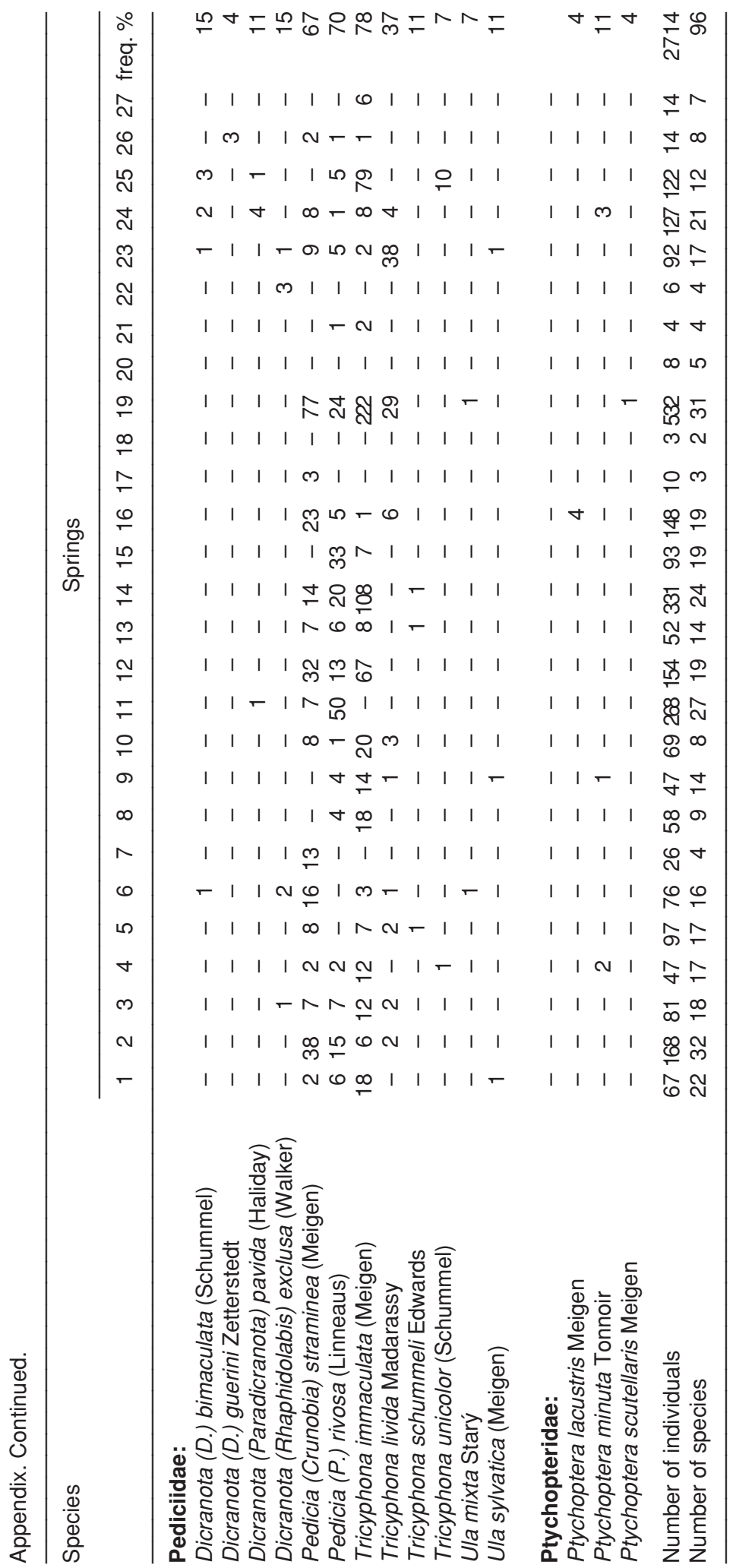

